\title{
Éditorial
}

\section{MODÉLISATION CINÉTIQUE DES PROCÉDÉS DE RAFFINAGE}

La difficulté de la modélisation des réacteurs dans le domaine du raffinage pétrolier résulte de la très grande complexité en termes de composition chimique des bruts pétroliers ainsi que de leur très grande variété de composition selon leur origine géographique. Il y a donc deux défis majeurs : accéder à une description analytique la plus complète possible de ces produits et décrire l'ensemble des réactions chimiques avec un niveau de détail suffisant pour prédire la structure des rendements et les qualités des produits (comme l'indice d'octane de l'essence par exemple).

Le processus de développement des modèles cinétiques a démarré très tôt dans l'industrie pétrolière. Il a subi de nombreuses évolutions depuis les années 60 avec une tendance lourde vers une complexité de plus en plus grande des modèles. Cette complexification résulte principalement d'une meilleure compréhension des phénomènes physico-chimiques observés, du développement de nouveaux outils analytiques donnant accès à une information moléculaire plus détaillée et de la montée en puissance des ordinateurs.

Lors de la construction d'un modèle, une des principales difficultés rencontrées est la représentation des flux de matière entrant et sortant du procédé. Habituellement, dans le domaine plus général de la chimie, ces flux sont décrits par leur débit et leur composition moléculaire, c'est-à-dire par la quantification relative des différentes espèces chimiques qui les constituent. Dans le domaine pétrolier, les flux sont souvent des mélanges beaucoup trop complexes pour pouvoir être représentés de cette manière. À titre d'exemple, un gazole commercial peut posséder jusqu'à plusieurs milliers de composés différents.

Historiquement, cette difficulté a été alors contournée en regroupant les composés ayant des propriétés voisines par famille commune en fonction du type de procédé étudié : on parle alors de modèles de regroupements ou modèles de lumping. Dans le domaine de la thermodynamique nonréactive, comme les composés pétroliers ont une faible polarité, les composés sont regroupés par familles de volatilité croissante appelées pseudo-corps. Avec une description des flux pétroliers à l'aide d'une dizaine de pseudo-corps et d'un modèle thermodynamique adéquate, il est alors possible de développer des modèles robustes pour un ballon flash, une distillation multi-étages, un train d'échange de chaleur, etc.

Lors de la modélisation de procédés réactifs (et souvent catalytiques), le regroupement par familles reste encore un art qui dépend de la connaissance du procédé, des techniques analytiques et de la puissance de calcul des ordinateurs disponibles au moment du développement du modèle. Cependant, la tendance générale a consisté à augmenter continûment le nombre de regroupements de manière à décrire de plus en plus finement les coupes pétrolières. À titre d'illustration, les modèles de craquage catalytique de distillats sous vide sont ainsi passés d'une description sous la forme de 3 lumps (regroupements de molécules) en 1970 à 10 lumps en 1976 et à 18 lumps en 1994. Une fois les regroupements définis, un schéma cinétique permet de traduire les relations des différentes familles entre elles.

Les modèles sont alors basés sur un module cinétique qui permet de suivre l'évolution de la quantité des différentes familles dans leur environnement réactionnel. L'avantage de ces modèles est leur grande simplicité de développement et d'utilisation. Leur principal inconvénient est qu'ils sont souvent dépendants du type de charge (mélange constitué par les réactifs et éventuellement 
les produits recyclés alimentant le réacteur) entrant dans le procédé et du type de catalyseur employé si le procédé est catalytique. Le second défaut est que le nombre de paramètres des modèles augmente en proportion avec le nombre de regroupements décrivant les flux, ce qui peut devenir limitant au moins au niveau de l'estimation des paramètres des modèles.

À l'opposé, d'autres modèles plus fondamentaux ont été développés à partir d'une description moléculaire des flux et d'un réseau réactionnel d'étapes élémentaires. Plusieurs équipes ont travaillé sur ce type d'approches : l'équipe de M.T. Klein qui s'appuie sur modèles LFER (Linear Free Energy Relationships) et les équipes de G.F. Froment et de G.B. Marin qui se basent sur la théorie des événements constitutifs (Single-Events) en sont des exemples parmi d'autres.

L'avantage des modèles mécanistiques est que le nombre de paramètres du modèle est relativement faible et que les valeurs de ces derniers sont indépendantes du type de charge. Leur inconvénient principal est qu'il faut avoir accès au détail moléculaire des flux, ce qui n'est possible que sur des mélanges de molécules bien identifiées. Une seconde difficulté concerne le réseau réactionnel dont la taille augmente de manière exponentielle avec le nombre et la taille des composés présents dans les flux. Il peut alors s'avérer nécessaire de développer des techniques de contournement permettant de limiter la taille du réseau, soit en regroupant les espèces, soit en limitant les réactions a priori ou en les sélectionnant au fur et à mesure de l'avancement de la réaction (cinétique Monte Carlo).

Pour gérer la difficulté liée à la caractérisation moléculaire des méthodes dites de reconstruction moléculaire ont été développées en parallèle des techniques analytiques de façon à pouvoir générer des mélanges de molécules (de 100 à 10000 molécules) dont les propriétés sont proches de celles accessibles par les techniques analytiques. Ces méthodes initiées dans les années 80 peuvent être regroupées en deux grandes familles : les méthodes de sélection qui modifient les composés du mélange et les méthodes compositionnelles qui adaptent les fractions molaires des molécules de mélanges prédéfinis. Toutes ces méthodes permettent au final d'obtenir des mélanges de composés qui servent ensuite de bases au développement de modèles cinétiques moléculaires.

Ce dossier présente une illustration des travaux réalisés à IFP Energies nouvelles sur la modélisation cinétique de procédés de transformation de coupes pétrolières complexes. Des méthodes de reconstruction moléculaire des coupes pétrolières ont ainsi été développées et appliquées à des coupes de complexité croissante : essences, gazoles et distillats sous vide. Elles s'appuient le plus souvent sur des développements récents de méthodes d'analyse, en particulier sur la chromatographie bidimensionnelle (GC2D). La génération et la gestion de réseaux réactionnels complexes par la méthode de modélisation par événements constitutifs sont illustrées au travers d'exemples en catalyse acide : isomérisation des paraffines légères, reformage catalytique d'essences légères et hydrocraquage de paraffines longues. Une extension de la méthode des événements constitutifs vers la catalyse métallique est également proposée pour la modélisation de la réaction de Fischer-Tropsch.

D. Hudebine et J.-F. Joly IFP Energies nouvelles 


\section{Editorial}

\section{CHEMICAL REACTION MODELLING OF REFINING PROCESSES}

The difficulty of modelling chemical reactors in the field of petroleum refining stems from the wide variety of chemical and structural isomers present in petroleum fractions and the large diversity in crude oil composition, which strongly depends on their geographical origin. There are, therefore, two major challenges: arriving at an analytical description of these products that is as complete as possible, and describing the chemical reactions with a sufficient level of detail in order to predict the yield structure of the effluent and their product qualities (such as the octane number of the naphtha fraction, for example).

The development of kinetic models began very early in the petroleum refining industry. It has undergone numerous advancements since the 1960s, with a strong trend towards an ever greater complexity in these models. This increase in complexity mainly resulted from a better understanding of the physicochemical phenomena, from the development of new analytical tools that gave access to more detailed molecular information, and from an increase in computing power.

In constructing a model, one of the main difficulties encountered is the representation of the input and output streams to and from the process. Usually, in the general field of chemistry, these streams are described by their flow rate and their molecular composition, i.e. by the relative abundance of the different chemical species that constitute the streams. In the petroleum industry, these streams are often far too complex mixtures to be represented in this manner. As an example, a commercial diesel may contain as many as several thousands different compounds.

Historically, this difficulty has been overcome by grouping compounds with similar properties into families or 'lumps': these models are therefore referred to 'lumped' models. The choice of the number and type of families depends on the process being studied, however. In the field of non-reactive thermodynamics, since petroleum compounds have a low polarity, the individual species are lumped into families of increasing volatility termed pseudo-components. With a description of oil streams using around ten pseudo-components and an appropriate thermodynamic model, it is then possible to develop robust models for a flash drum, a multi-stage distillation, a heat exchange train, etc.

In the field of reaction modelling, lumping by families still remains an art that depends on the knowledge of the process, on the analytical capabilities, and on the computing power available at the time of the model development. However, the general trend has consisted in continually increasing the number of lumps in order to describe the petroleum fractions ever more precisely. This is illustrated by the evolution of the kinetic models for catalytic cracking of vacuum gas oils, which started from a model with 3 lumps in 1970 to 10 lumps in 1976 and 18 lumps in 1994. Once the lumps have been defined, a reaction network identifies the relations between the different families.

In this approach, the models are based on a kinetic module that allows to track the amount of each family in their reactional environment. The advantage of these models is the great simplicity, both in their development and in their use. Their main drawback is that they often depend on the type of feed (mixture supplying the reactor and composed of reagents and possibly recycled products) to the process and on the type of catalyst employed if the process is catalytic. The second weakness of lumped models is that the number of parameters of the model increases with the number of lumps describing the streams, which may become a limiting factor, at least during the estimation of the model parameters.

Conversely, other more fundamental models have been developed based on a molecular description of the streams and an elementary step reaction network. Several teams have developed this type of approach: M.T. Klein's team, using LFER (Linear Free Energy Relationships) based models, and both the teams of G.F. Froment and of G.B. Marin, based on the concept of single events, are just a few of several approaches. 
The advantage of mechanistic models is that the number of parameters of the model is relatively small and that their values do not depend on the type of feed. Their main drawback is that one needs to have access to a molecular composition of the streams, which is only possible with clearly identified mixtures of molecules. A second difficulty concerns the reaction network, whose size increases exponentially with the number and size of the compounds present in the streams. It may thus prove necessary to develop workaround techniques that limit the reaction network size, either by lumping species, or by putting on a priori limit on the reactions, or selecting the reactions 'on the fly' as a function of the reaction extent (Monte Carlo kinetics).

To overcome the difficulty related to molecular characterization, so-called molecular reconstruction methods have been developed in parallel to improved analytical techniques in order to create mixtures of molecules (between 100 and 10000 molecules) with properties that are similar to those given by the available analyses. These methods, initiated in the 1980s, can be grouped into two major families: selection methods, which modify the compounds in the mixture, and compositional methods, which adapt the mole fractions of the molecules in pre-defined mixtures. All these methods ultimately enable obtaining mixtures of molecules that then serve as a basis for the development of molecular kinetic models.

This dossier illustrates the work carried out at IFP Energies nouvelles on the kinetic modelling of transformation processes for complex petroleum fractions. Molecular reconstruction methods have been developed and applied to petroleum fractions of increasing complexity: naphthas, atmospheric gas oils and vacuum gas oils. They most often draw on information from recent developments in analytical methods, in particular in two-dimensional chromatography $(\mathrm{GC} \times \mathrm{GC})$. The generation and management of complex reaction networks using the single events modelling approach are illustrated through examples of acid-catalyzed processes: isomerization of light paraffins, catalytic reforming of light naphtha and hydrocracking of long paraffins. An extension of the single events method towards metal catalysis is also proposed for the modelling of the Fischer-Tropsch reaction.

D. Hudebine and J.-F. Joly IFP Energies nouvelles 